Paideusis

\title{
Open-mindedness in Three Dimensions
}

\section{Chris Higgins}

Volume 18, Number 1, 2009

URI: https://id.erudit.org/iderudit/1072338ar

DOI: https://doi.org/10.7202/1072338ar

See table of contents

Publisher(s)

Canadian Philosophy of Education Society

ISSN

0838-4517 (print)

1916-0348 (digital)

Explore this journal

Cite this article

Higgins, C. (2009). Open-mindedness in Three Dimensions. Paideusis, 18(1), 44-59. https://doi.org/10.7202/1072338ar
Article abstract

In this programmatic essay, I approach the question "What is open-mindedness?" through three more specific questions, each designed to foreground a distinct dimension along which the analysis of open-mindedness might proceed: When is open-mindedness? What is not open-mindedness? and, Where is open-mindedness? The first question refers to the temporal dimension of open-mindedness, which I analyze in terms of Dewey's distinction between recognition and perception and the psychoanalytic concept of disavowal. The second question refers to the dialectical dimension of open-mindedness, to what the many aspects of closed-mindedness reveal about open-mindedness. Here I recall Aristotle's doctrine of the mean. The third question refers to the dimension of scale, asking what open- and closed-mindedness look like on the interpersonal and social levels. To bring out this third dimension, I draw on Jonathan Lear's reading of the Republic and psychoanalytic group dynamics theory. Through these three related inquiries I show the range of this central intellectual virtue and bring out its connections to two central, related features of the moral life: the need for integration and the need for openness to newness and complexity.
This document is protected by copyright law. Use of the services of Erudit (including reproduction) is subject to its terms and conditions, which can be viewed online.

https://apropos.erudit.org/en/users/policy-on-use/ 


\title{
Open-mindedness in Three Dimensions
}

\author{
CHRIS HIGGINS \\ University of Illinois at Urbana-Champaign
}

\begin{abstract}
In this programmatic essay, I approach the question "What is open-mindedness?" through three more specific questions, each designed to foreground a distinct dimension along which the analysis of openmindedness might proceed: When is open-mindedness? What is not open-mindedness? and, Where is openmindedness? The first question refers to the temporal dimension of open-mindedness, which I analyze in terms of Dewey's distinction between recognition and perception and the psychoanalytic concept of disavowal. The second question refers to the dialectical dimension of open-mindedness, to what the many aspects of closed-mindedness reveal about open-mindedness. Here I recall Aristotle's doctrine of the mean. The third question refers to the dimension of scale, asking what open-and closed-mindedness look like on the interpersonal and social levels. To bring out this third dimension, I draw on Jonathan Lear's reading of the Republic and psychoanalytic group dynamics theory. Through these three related inquiries I show the range of this central intellectual virtue and bring out its connections to two central, related features of the moral life: the need for integration and the need for openness to newness and complexity.
\end{abstract}

\begin{abstract}
What [one] gets and gives as a human being, a being with desires, emotions, and ideas, is not external possessions, but a widening and deepening of conscious life- a more intense, disciplined, and expanding realization of meanings.... And education is not a mere means to such a life. Education is such a life. To maintain capacity for such a life is the essence of morals. For conscious life is a continual beginning afresh.
\end{abstract}

John Dewey, Democracy and Education ${ }^{1}$

\section{Introduction}

I propose that we approach the question "What is open-mindedness?" through three more specific questions, each designed to foreground a distinct dimension along which the analysis of openmindedness might proceed: When is open-mindedness? What is not open-mindedness? and, Where is open-mindedness?2 Let me explain what I mean by each, and why each represents a distinct and useful perspective on OM.

The question "When is open-mindedness?" is of course indebted to Nelson Goodman. ${ }^{3}$ To see why it is useful to analyze OM along a temporal dimension, imagine the encounter with an alien idea or

${ }^{1}$ John Dewey, Democracy and Education: An Introduction to the Philosophy of Education (New York: Macmillan, 1916), 359-60.

${ }^{2}$ Henceforth I will abbreviate open-mindedness as OM.

3 I am referring to Nelson Goodman, “When Is Art?,” in Ways of Worldmaking (Indianapolis: Hackett, 1978), 5770 .

(C) Copyright 2009. The author, Chris Higgins, assigns to Paideusis the right of first publication and educational and non-profit institutions a non-exclusive license to use this document for personal use and in courses of instruction provided that the article is used in full and this copyright statement is reproduced. Any other usage is probibited without the express permission of the author. 
value as a sequence with three basic moments: (1) idea is outside awareness; (2) idea comes into awareness; (3) idea is taken in and brought into relation with our existing ideas. ${ }^{4}$ In the first section, I will argue that OM can occur, or fail to occur, at each of these moments, and that in each we can learn something different about what OM entails. In particular, I will suggest that at the beginning of this sequence the worry for OM lies in the habits of recognition described by Dewey; while at the end the concern tends more toward what Freud taught us to call disavowal.

In the second section, I explore some complications in the analysis of $\mathrm{OM}$ as a virtue. Specifically, I ask: what vice, or vices, correspond to this virtue? If the opposite of OM is closedmindedness, and we allow that closed-mindedness sometimes takes principled forms, then we may be forced to conclude that $\mathrm{OM}$ is sometimes a vice. ${ }^{5}$ To avoid this conclusion, I return to Aristotle's doctrine of the mean and develop a tripartite (rather than a binary) model of OM. Attending to this dialectical dimension reveals $\mathrm{OM}$ as a multi-faceted intellectual virtue, defined by a cluster of related contrasts.

If you want to look at something, it is helpful to know where to look for it. Thus, in the third section, I ask, "Where is open-mindedness?" The answer may seem obvious. After all, if OM is an intellectual virtue then we simply need to look at intellects, to examine how individual minds work. And yet, are minds really individual possessions? Well, yes, but this is only part of the story. Some of the chief forces shrinking our mental apertures occur at larger scales. For example, an ordinarily openminded individual may become rigid and dogmatic when caught up in the powerful dynamics of group life. And the disposition to be receptive to rival claims, missing facts, and novel ways of life may be of no use if our contact with such things is foreclosed by forms of closed-mindedness built into our very cultures. The point is not simply the obvious one that mind is affected by forces outside it. In the third section, I will take up the idea that we find mind itself, opening and closing, at all of these various scales. Here I draw on Jonathan Lear's reading of Plato's Republic and on psychodynamic Group-as-aWhole Theory.

\section{When Is Open-mindedness?}

When does $\mathrm{OM}$ occur or fail to occur? The typical answer focuses on the moment when someone confronts an unfamiliar idea. Does the person in question reject this idea out of hand, simply on account of its strangeness, or give it a fair hearing? Without denying that this is one of the moments in which we show ourselves to be open- or closed-minded, I want to suggest that it is not the only, or even the most important, one. Much occurs both before and after this paradigmatic moment that is important to the analysis of OM. What could possibly occur before someone confronts a challenging idea? The answer, of course, is its coming into awareness. But this is a trivial step, some may object. To this I respond that in fact it often fails to occur.

"In what follows, I will use the term "ideas" as a shorthand for novel ideas, rival values, and the full range of characteristic objects of open- and closed-mindedness. It seems that it is appropriate to speak of OM in any case where one is confronted by a challenge to one's beliefs and schemas of understanding. This may mean facts that don't fit our theories or theories that don't fit our facts. It may mean rival positions in debates we have already joined or challenges to our sense of what is worth worrying about in the first place. It includes not just the contrary (that which we have heretofore tended to reject), and the marginal (that which we have heretofore tended to discount), but also the anomalous (that which we barely know how to notice or name).

${ }^{5}$ If something is a virtue, it is never a vice. However, it is true that: (1) sometimes the courageous response (for instance) will be to flee-in some situations this will be the mean between cowardice and foolhardiness; (2) it may be practically unwise to treat a situation as one that calls for a courageous response when it is better understood as one calling for patience, kindness, etc. I discuss this further below. 
Much that might challenge one's views simply goes unnoticed and for reasons not unrelated to open-mindedness. In many arenas of understanding, our schemas make salient for us precisely those aspects of the world that fit them. ${ }^{6}$ We could make this point with Gadamer or Wittgenstein, Oakeshott or Dewey. For Dewey, a human being inhabits not simply her "surroundings," but an effective "environment." "The things with which a man varies," Dewey writes, "are his genuine environment."7 To identify a person's surroundings you need only a G.P.S. tracking device. To understand a person's environment, you need to know a good deal about their past experiences, present purposes, and future expectations. You would have to understand how their habits, practices, and preconceptions make some features of the world salient and others virtually invisible. ${ }^{8}$ I say virtually, because we do often have experiences of being "pulled up short," to use Gadamer's expression for the inevitably distressing moments where we notice something about the limitations of our noticing. ${ }^{9}$ Whether we deal with what we notice in an unprejudiced manner remains important, but if we understand OM as a capacity of persons to make contact with more of the complexity of the world then what we do and don't notice is of fundamental importance.

To highlight this point we can consider a somewhat extreme example: the neurotic. The neurotic, Jonathan Lear writes, lives in an "idiopolis," a world shaped in fundamental ways by his hopes and fears. ${ }^{10}$ To the neurotic - and indeed to all of us insofar as we resemble the neurotic - the moment of confrontation is usually preempted. Lear offers the example of a patient of his who "organized the world in terms of disappointment." 11 For this woman, the problem was not being closed-minded, in the usual sense, toward life's hopeful signs. For this woman there were no hopeful signs; disappointment really did lurk around every corner. As Lear explains, this patient was

not only adept at interpretation - turning what, on the surface, looked like significant social and professional accomplishments, into defeats; she was also talented at acting in ways that would ensure a disappointing outcome. She implicitly or unconsciously knew how to interact with others in ways that would provoke them to let her down. ${ }^{12}$

The point of extending the analysis of $\mathrm{OM}$ along a temporal dimension was that $\mathrm{OM}$ itself tends to look somewhat different depending on when it occurs. When we focus on the moment of confrontation with the unfamiliar idea (let us call this the liminal moment), as we typically do, we tend to view $\mathrm{OM}$ as a process of vetting, as a disposition to value truth over comfort, and so on. In this "subliminal" phase I have been discussing, OM is closer to what Dewey calls full and lingering

${ }^{6} \mathrm{~A}$ person expecting the floor to extend around a corner, where it actually suddenly dips, will of course not float on air because of his framing of the situation. But for every example of this sort there are many others where a person's habits, purposes, and expectations do shape in significant ways the world he comes to inhabit.

Dewey, Democracy and Education, 11.

${ }^{8}$ On the role of occupations in determining one's environment, see Ibid., 309-310; cf. John Dewey, Experience and Education (1938), The Kappa Delta Pi Lectures (NY: Simon and Schuster, 1997), 37. I discuss this idea at length in Chris Higgins, "Dewey's Conception of Vocation: Existential, Aesthetic, and Educational Implications for Teachers," Journal of Curriculum Studies 37, no. 4 (2005), 441-464.

${ }^{9}$ Hans-Georg Gadamer, Truth and Method (1960), 2nd rev., "Continuum Impacts," ed., trans. rev. by Joel Weinsheimer and Donald Marshall (NY: Continuum, 2004), 270; cf. Deborah Kerdeman, "Pulled up Short: Challenging Self-Understanding as a Focus of Teaching and Learning," Journal of Philosophy of Education 37, no. 2 (2003), 293-308.

10Jonathan Lear, "An Interpretation of Transference," in Open Minded: Working out the Logic of the Soul (Cambridge, MA: Harvard University Press, 1998), 69-73.

11Jonathan Lear, Happiness, Death, and the Remainder of Life: The Tanner Lectures on Human Values (Cambridge, MA: Harvard University Press, 2000), 65.

12Ibid., 66. 
perception. In Art as Experience, Dewey distinguishes this from what he calls bare recognition, or "perception arrested before it has the chance to develop fully." 13 Recognition, of course, is an incredibly useful ability. Without categories and habits, we confront a chaos we cannot navigate. At the same time, Dewey avers, to be fully alive requires cultivating moments and modes of greater responsiveness, moments where we try to take in the richness of the diverse things we ordinarily "dispose" of with our cognitive shortcuts. For Dewey, we may have wider range in our habits of recognition than Lear's neurotic, but we are kidding ourselves if we deny that we all actively shrink the world in countless ways, to what we can use and what we can bear. To be open-minded in the subliminal phase, then, requires not fairness to conflicting ideas but sensitivity to what might, what must, be left out in any of our initial surveys of some aspect of the world.

Earlier I spoke of both a "before" and an "after" relative to the moment of confrontation with rival claims and novel ideas. Even if you now accept my assertion that there is an important subliminal phase, it may seem counterintuitive to suggest a third act in the drama of OM. After all, one might think that the liminal phase must result either in acceptance or rejection of the novel idea, and that in either case the story is over. If the person has, as it were, spit out the idea then we can consider his future openness to the idea; but this would mean a new confrontation rather than a later stage in the initial process. If the person has ingested the idea, then we do not need to ask about any future openness towards the idea. Or do we? To continue with the alimentary metaphor: after ingestion comes digestion or in some cases indigestion. What is the equivalent of digestion and indigestion when we are talking about food for thought?

Imagine two friends $\mathrm{A}$ and $\mathrm{B}$. A has an interpretation $(I)$ of some set of events $(E)$, an interpretation she feels strongly about. But B brings to her attention an example $(e)$ that seems to contradict her interpretation. Here is the moment of confrontation. About this moment, we will want to know whether A took B's contention seriously or not. Notice that this is not the same as asking whether A accepts or rejects the idea. What matters is whether A considered carefully and fairly whether something really happened, whether $e$ is really what happened, whether $e$ really is an instance of $E$, whether this poses real problems for $I$, and so on. If A engages B's contention in this way, we will want to call A open-minded regardless of whether I ultimately survived B's challenge.

What if A fails to consider such questions in a serious fashion? Certainly, if A rejects B's contention out of hand, ignoring or begging these questions we have just laid out, then we have a paradigmatic example of close-mindedness. What I want to suggest, however, is that even in the case where A accepts B's contention, if A rushes to judgment then A has failed to be truly open-minded. Being open-minded about the possibility that $e$ contradicts $I$ entails taking that possibility seriously, and this in turn entails looking at it closely and carefully, fairly and fully. When someone ingests an idea without really chewing it over, there occurs the intellectual equivalent of indigestion. The idea becomes a part of us-we can trot it out on occasion-but it sits like a lump in our stomach.

There are two different ideas here. One has to do with what constitutes genuine openmindedness in the liminal phase. In the next section, I will develop this idea that gullibility is just as much a form of closed-mindedness as intransigence. However, for our purposes here, I want to pursue the more general idea that the issue of open-mindedness often remains unresolved long after the liminal phase. Specifically, I want to consider the idea that not only might we swallow an idea too quickly, but that we might accept an idea for the very purpose of not engaging with it. This would make little sense if we were free of internal divisions. But of course, such is not our lot.

Indeed, as Freud famously showed, all of us at various points and in various ways invest a good deal of energy defending against the awareness or the force of our own ideas. It has become common to speak of this as repression but in fact repression is only one defense among many. Indeed, repression

13John Dewey, Art as Experience (1934) (NY: Perigree/Putnam, 1980), 52. I work with Dewey's recognition/perception distinction in detail in Chris Higgins, "Instrumentalism and the Clichés of Aesthetic Education: A Deweyan Corrective," Education and Culture 23, no. 3 (2008), 7-20. 
may be the outlier, as it relies on the taxing strategy of holding the dangerous idea out of consciousness. Many of the other defenses are more subtle and economical. Consider the defense known as disavowal. What is disavowed is not the piece of reality that challenges my belief, but its challenge. The idea is accepted but trivialized or compartmentalized. The French psychoanalyst Octave Mannoni famously captured the logic of disavowal in a phrase: "Je sais bien, mais quand même..." (I know very well, but all the same ..... ${ }^{14}$

Thus, depending on when it occurs, open- and closed-mindedness appear slightly differently. First the closed-minded person appears as a somnambulist, whose habits and schemas of recognition narrow his commerce with the complexity of the world before any conscious confrontation and refusal takes place. In the liminal phase, closed-mindedness takes the more familiar forms of hastiness, prejudice, and obtuseness in the face of challenges to one's beliefs. Finally, there is the special but real possibility of internal closed-mindedness, in which an idea seemingly acknowledged continues to be held at bay by some or another intrapsychic stratagem such as disavowal. OM in turn appears first as a sort of aesthetic sensitivity, a capacity to perceive the uniqueness of a complex, irreducible situation. ${ }^{15}$ Then it takes the more familiar forms of humility and impartiality. Finally, it seems to represent a type of integrity, a capacity to avow the stranger within and reintegrate the self. In describing OM at each of these stages, we find ourselves using virtue terms. Let us turn now to the question of what it means to think of $\mathrm{OM}$ as an intellectual virtue.

\section{Some Complications in the Analysis of Open-mindedness as a Virtue (What Is not Open-mindedness?)}

I believe that William Hare has put us on the right track in conceiving of OM as an intellectual virtue. ${ }^{16}$ I share the intuition that OM fits the model of the virtues and that we are right to count it among the

${ }^{14}$ Octave Mannoni, "I Know Well, but All the Same..." (1969) in Perversion and the Social Relation, eds. Molly Anne Rothenberg, Dennis A. Foster, and Slavoj Žižek, trans. G.M. Goshgarian (Durham: Duke University Press, 2003), 68-92.

${ }^{15}$ Here we are close to Aristotle's idea of phronesis or practical wisdom, developed in Book VI of the Nicomachean Ethics. For two important modern interpretations of this concept, see Martha C. Nussbaum, "The Discernment of Perception: An Aristotelian Conception of Private and Public Rationality," in Love's Knowledge: Essays on Philosophy and Literature (New York: Oxford, 1990), 54-105; and, Hans-Georg Gadamer, "The Hermeneutic Relevance of Aristotle," (1960) in Truth and Method, 2nd rev., "Continuum Impacts," trans. Joel Weinsheimer and Donald Marshall (NY: Continuum, 2004), 309-319.

${ }^{16}$ In his early work on the subject, Hare gravitates more toward talk of traits and attitudes, than of virtues. See William Hare, Open-Mindedness and Education (Montreal: McGill-Queen's University Press, 1979); and, William Hare, In Defense of Open-Mindedness (Kingston: McGill-Queen's University Press, 1985). For an early, if indirect, reference to open-mindedness as an intellectual virtue, though, see Hare, Open-Mindedness and Education, 6. Hare begins using the language of the virtues more explicitly in later work such as William Hare, What Makes a Good Teacher: Reflections on Some Characteristics Central to the Educational Enterprise (London, Ontario: The Althouse Press, 1993); William Hare, “The Socratic virtues in teaching," Wesleyan Graduate Review 1, no. 1 (1997): 15-28, reprinted as William Hare, Teaching and the Socratic Virtues (St. Johns, Newfoundland: Memorial University, 1995). Virtue talk is standard by the time we get to William Hare, "Teaching and the Barricades to Inquiry," Journal of General Education 49, no. 2 (2000), 88-109; and, William Hare, "Is It Good to Be Open-Minded?," International Journal of Applied Philosophy 17, no. 1 (2003), 73-87. In his introduction to a recent special issue on open-mindedness, Hare defined it as: "an intellectual virtue properly ascribed when an individual or a community is disposed to take into account all that is relevant to forming a sound judgment and likewise disposed to reconsider judgments already made, or in formation, in the light of emerging difficulties, especially when it is tempting to avoid acting in these ways." [William Hare, "The Ideal of Open-Mindedness and Its Place in Education," Journal of Thought 38, no. 2 (2003): 3-4.] 
human excellences. Further, I believe that a virtue theorization can help us make sense of openmindedness as an educational aim, but only if we take care to distinguish robust and nominal versions of virtue ethics.

The nominal version sprinkles in talk of character along with talk of principles and consequences. According to this approach, virtue theory can be slotted in alongside consequentialist, deontological, contractarian, and other modern moral theories. There is, however, also a much more robust and radical approach to virtue ethics. There is a large and growing body of work-from the early, groundbreaking essays of G.E.M. Anscombe, Philippa Foot, and Iris Murdoch to the more recent interventions of Alasdair MacIntyre, Bernard Williams, Martha Nussbaum, and Charles Taylordevoted to revealing the narrowness of modern morality and to recovering displaced ethical concepts. ${ }^{17}$ This renaissance of aretaic or eudaimonistic ethics is too rich and multifaceted to treat fully here, but I do want briefly to mention how this phrase "virtue theory" is potentially doubly misleading. ${ }^{18}$

First, it has been central to the revival of eudaimonistic ethics to show that modern morality has become overly preoccupied with duty, obligation, and altruism. As Bernard Williams points out,

${ }^{17}$ See G.E.M. Anscombe, "Modern Moral Philosophy," Philosophy (The Journal of the Royal Institute of Philosophy) 33, no. 124 (1958), 1-19; Philippa Foot, "Moral Arguments," Mind, New Series 67, no. 268 (1958), 502-513, reprinted in Philippa Foot, Virtues and Vices and Other Essays in Moral Pbilosophy (Oxford: Basil Blackwell, 1978), 96-109; Philippa Foot, "Moral Beliefs," Proceedings of the Aristotelian Society 59 (1958), reprinted in Foot, Virtues and Vices, 110-31; Iris Murdoch, "Vision and Choice in Morality," Proceedings of the Aristotelian Society 30 (supplemental: Dreams and Self-Knowledge) (1956), 32-58; reprinted in Iris Murdoch, Existentialists and Mystics: Writings on Pbilosophy and Literature, ed. P. Conradi (NY: Penguin, 1998), 76-98; Alasdair MacIntyre, After Virtue: A Study in Moral Theory (South Bend, IN: University of Notre Dame Press, 1981; reprint, 2nd ed. with a new prologue, 1984; 3rd ed. with a new introduction, 2007); Bernard Williams, Ethics and the Limits of Pbilosophy (Cambridge, MA: Harvard University Press, 1985); Martha C. Nussbaum, The Fragility of Goodness: Luck and Ethics in Greek Tragedy and Pbilosophy (Cambridge: Cambridge University Press, 1986); Charles Taylor, The Sources of the Self: The Making of the Modern Identity (Cambridge, MA: Harvard University Press, 1989). See also Edmund L. Pincoffs, "Quandary Ethics," Mind 80 (1971), 552-571; reprinted Stanley Hauerwas and Alasdair MacIntyre, eds., Revisions: Changing Perspectives in Moral Philosophy (Notre Dame: University of Notre Dame Press, 1983): 92-112; M. Stocker, "The Schizophrenia of Modern Ethical Theories," Journal of Philosophy 73, no. 14 (1976), 433-466; John McDowell, "Are Moral Requirements Hypothetical Imperatives?," Proceedings of the Aristotelian Society 52 (supplemental) (1978), 1329; Susan Wolf, "Moral Saints," Journal of Philosophy 79, no. 8 (1982), 419-435; John Cottingham, "The Ethics of Self-Concern," Ethics 101, no. 4 (1991), 798-817.

${ }^{18}$ The term aretaic is a modern English adjective made from the ancient Greek arête, which is hard to translate since it has ethical meanings not captured by our term "excellence" but is broader than the moralistic sounding "virtue." Ugly though it is, the coinage serves not to assimilate this ancient notion of excellences too quickly to our modern categories. Aretai are excellences of character that are at once dispositions to act for the good in concrete situations and part of the substance of a life well-lived. Eudaimonia is sometimes translated as happiness, but it is unlike modern concepts of happiness in important respects. For example, it does not refer to fleeting moods but to the shape of one's life as a whole. Furthermore, while happiness is typically understood as a subjective experience, endaimonia refers to objective qualities of that life. Whereas it might seem strange to challenge a person's self-report about their own happiness or lack thereof, it might well be others who have the clearest perspective on whether a person's life truly exhibits eudaimonia. Bernard Williams and Richard Kraut prefer "well-being" as a translation, but subjective connotations seem to have overtaken this phrase as well. The best option may be "flourishing," or a phrase such as "faring well" or "living well. " The advantage of leaving the term in the Greek or using the neologism "eudaimonistic" is that it reminds us of the distance of this concept from our modern preconceptions about happiness and well-being. For more on eudaimonia, see, for example, J.L. Ackrill, "Aristotle on Eudaimonia," in Essays on Aristotle's Ethics, ed. Amelie Rorty (Berkeley: University of California Press, 1980), 15-33; John McDowell, "The Role of Eudaimonia in Aristotleís Ethics," in Essays on Aristotle's Ethics, ed. Rorty, 359-376; Richard Kraut, "Two Conceptions of Happiness," The Philosophical Review 88, no. 2 (1979), 167-197; Williams, Ethics and the Limits of Philosophy, chap. 3; Julia Annas, The Morality of Happiness (New York: Oxford University Press, 1993), chap. 1. I reconstruct the revival of eudaimonistic ethics in detail in The Good Life of Teaching: Toward a Virtue Ethic of Teaching (Wiley-Blackwell, forthcoming), chap. 1. 
morality makes it difficult to challenge this focus by making it seem that the only alternative to duty is inclination, the only alternative to altruism, base self-interest. Thinkers such as Williams have sought to restore the first-personal dimensions of ethics. Questions of identity and self-regard, ambition and life projects, may be extra-moral, but they are at the heart of ethics when more broadly conceived. So we must be cautious in speaking of virtue ethics since the term "virtue" did not disappear in modernity, it simply took on a moralistic tone. ${ }^{19}$ What makes philosophical retrieval difficult is that terms are often not lost but distorted.

The term "theory" is also misleading, since at least in some formulations the only thing that unites such disparate neo-Platonic and neo-Aristotelian thinkers such as Murdoch, Macintyre, Nussbaum, Taylor and Williams is their commitment to ethical "anti-theory." 20 Central to what I am calling the robust approach to virtue ethics is a critique of the thinness and proceduralism of much modern moral philosophy. We move from visions of the good, accessible only in the thick languages of description that accompany concrete forms of life (and thus inseparable from history and culture, from aesthetics, religion and politics), to attempts to set out in terms acceptable to any rational person a set of universally binding proscriptions on conduct. For the critics of modern morality, the genre of theory is itself distorting of the moral life. We have come to look for rules and decision procedures when, according to the robust "virtuists," what is needed is precisely vision and judgment: the ability to take in finely and fully what concrete situations demand of us. To develop the capacity to see what is salient in a situation requires exemplars and practice. There is no rule book for the moral life.

So, what does it mean to describe open-mindedness as a virtue in this robust sense? What are the advantages to conceiving of open-mindedness in this way? First, it helps us to understand how openmindedness has not only narrowly moral, but broadly ethical import. ${ }^{21}$ It is not a dour prescription but a positive ideal. It certainly helps in treating others well to be open-minded, but it is at the same time a good for the person who develops this capacity. It is a candidate virtue because it is part of leading a full, meaningful, and excellent life to be open-minded. Thus, open-mindedness is not to be confined to so-called "moral education." It is part of our ideal of an educated person and, as such, is relevant to every aspect of the curriculum, formal and informal.

Second, imagine what would become of open-mindedness were it not theorized in the robust virtue direction I have outlined. We can be fairly certain teachers would be given three-day, if not threehour, workshops on how to teach for open-mindedness. Lesson plans would state that such and such an activity leads to open-mindedness. Or perhaps there would be a school-wide assembly so that the student body might catch the spirit. My point here is the familiar one that schools gravitate toward what Philip Jackson called the mimetic outlook on teaching, in which teaching is viewed as the transmission of detachable bodies of information and skills, and away from the "transformative" tradition, in which teaching is seen as a more fundamental shaping of the person. ${ }^{22}$

What virtue talk does for open-mindedness right away, then, is lift it clear of this idea that openmindedness might be a mere matter of attitude or technique. Putting up a poster of a kitten snuggling with a puppy will not inspire open-mindedness in students. And as we just noted, if open-mindedness is

${ }^{19}$ On this, see Jerome B. Schneewind, “The Misfortunes of Virtue," in Virtue Ethics, eds. Roger Crisp and Michael Slote (Oxford: Oxford University Press, 1997).

${ }^{20}$ See, for example, Stanley G. Clarke and Evan Simpson, eds., Anti-Theory in Ethics and Moral Conservatism (Albany: SUNY Press, 1989).

${ }^{21}$ I think this ethical/moral distinction is ultimately more important than the traditional moral/intellectual distinction. For Aristotle, phronesis is counted among the intellectual virtues since it represents excellence in one manner of thinking, but it is fundamental to moral conduct. For something to count as virtue, it must be part of the fabric of a good life. Some such excellences lean toward other regard, some toward self-regard. All are bound up with modes of perception and deliberation in their functioning.

22Philip Jackson, "The Mimetic and the Transformative: Alternative Outlooks on Teaching," in The Practice of Teaching (New York: Teachers College Press, 1986), 115-145. 
a virtue, it cannot be replaced by a decision procedure. There is neither a technique for being openminded nor is there a technique for teaching others to be open-minded. Thus, open-mindedness cannot be packaged into discrete lessons in education or teacher education. Notice, as regards the nominal/robust distinction, that recent talk of the dispositions has not proved much of a corrective to this mimetic conception of teaching and teacher education, whereas anything roughly Aristotelian in origin should be incompatible with such technicism and reductivism in the moral life.

For Aristotle, we learn the virtues through emulation and practice. One becomes virtuous slowly and implicitly, if at all. The courageous person has had the good fortune of growing up around courageous adults and of searching for the courageous action in concrete situations which further instruct him on what courage really means. Thus, the trick in being courageous is not willing yourself to be so: the courageous person has learned to want to do the courageous thing. She has learned to put fear in its place. ${ }^{23}$ Thus, casting open-mindedness as a virtue in the Aristotelian sense spares it the horrible fate of becoming, dare I say it, an "educational objective," while helping us understand its place in our ideals of the educated person and notions of human flourishing.

Let us now push our analysis of open-mindedness as a virtue further by posing the question: what is its opposite? Here is where Aristotle's theory of the mean is especially helpful. ${ }^{24}$ For Aristotle, every virtue has not one, but two opposites. Consider again the example of courage. The courageous person is certainly not cowardly, but neither is the excellence he displays the polar opposite of cowardliness. A coward is overly ruled by fear. For Aristotle, however, it is also and equally possible to be too little moved by fear. The person who abandons what he or she cares about at the first sign of danger is cowardly; the person who never retreats for any reason, or who even seeks risks for its own sake, is foolhardy. For Aristotle the virtue of courage amounts to having the right relationship to fear, to being appropriately moved by fear in light of the concrete details of the situation in which one finds oneself:

The man, then, who faces and who fears the right things and with the right aim, in the right way and at the right time, and who feels confidence under the corresponding conditions, is courageous; for the courageous person feels and acts according to the merits of the case and in whatever way reason directs. ${ }^{25}$

When Aristotle refers to virtue as a mean between two extremes, however, there are two things that he certainly does not intend. One, he is not imagining that we can calculate the exact location of each vice and then derive the midway point with some sort of mathematical precision. The other common misunderstanding is that virtuous action is always moderate in character. The courageous person may, given the particulars of the situation, decide to put his life in mortal peril or run away at the highest speed. Since it is impossible to know the exact location of the mean, the question for the courageous person is not simply, what does courage demand, but rather the double-question: am I being cowardly here? am I being foolhardy?

This triadic model of virtue, in which we understand every virtue as flanked by a pair of vices, is specifically helpful when it comes to the analysis of open-mindedness. Typically debates over openmindedness observe the following pattern. First someone claims that open-mindedness is a virtue. Next, someone objects that one can be too open-minded, that refusing to have truck with certain ideas

${ }^{23}$ For Aristotle's discussion of courage, see Nicomachean Ethics: II, 1104a28-1104b3; II, 1107a28-1107b8; and III, $1115 \mathrm{a} 6-1117 \mathrm{~b} 23$.

${ }^{24}$ For the doctrine of the mean, see Aristotle, Nicomachean Ethics II, 1106a14-1109b29.

${ }^{25}$ This is Jonathan Lear's translation of Aristotle, Nicomachean Ethics II, 1115b17-20. See Lear, Happiness, Death, and the Remainder of Life, 63. 
itself can be a virtue. ${ }^{26}$ For example, imagine a young person smitten by one idea after another, engaging each only superficially, condemned to a sort of incoherent wandering through life. Or, worse, imagine someone drawn into an absurd and dangerous cult because he or she was "all too openminded" when the cult's adherents made their pitch. The openness camp will probably retort that open-mindedness can and must be combined with reflective skepticism. ${ }^{27}$ And yet this response seems to give too much away. We do not want to construe openness as unreflective or uncritical, and then have to assign a detail of critical thinking bodyguards to protect it. Recall the courage example. We do not say that courage is not always a virtue because sometimes it is wise to run away. The foolhardy person is not overly courageous, but lacking insight into what courage means in the given situation. ${ }^{28}$ If open-mindedness is truly a virtue then one cannot be too open-minded.

Let us, then, attempt to recast open-mindedness on a triadic model. As a rough sketch let us say that to be open-minded is to allow novel ideas and rival values to interact with our preexisting ideas to the right degree and in the right way given the particular situation and the overarching ethical quest of leading a flourishing life. Rather than asking what is the opposite of this as in a binary model, let us instead ask what pair of opposites flank this mean. The answer then becomes clear. One can fail to be open-minded by allowing ideas too little purchase or too much. The key here is this modifier "too." The contrast is not between restricted and easy access, a binary contrast that we might be tempted to label closed and open. Once we label things this way, OM is sometimes a virtue and sometimes a vice. Instead, we say that the open-minded person finds his way between the extremes of giving novel ideas too little purchase and too easy access. The open-minded person, like the courageous one, must constantly ask himself two questions: am I being too dogmatic, too defensive, too quick to judge? and am I being too impressionable, too gullible, too intellectually self-abasing?

If courage is about having the right relation to fear, open-mindedness seems to be about having the right relation to novel ideas, and this relation seems to involve two principles, two goods: one concerning the integrity of my life history and one about making contact with reality. We reap both

${ }^{26}$ See, for example, the paper presented by Daniel Cohen (co-authored by George Miller) at the conference where the papers in this special issue originated. [Daniel H. Cohen and George Miller, "Gods, Gadflies, and Bulldog Tenacity: In Praise of Closed-Mindedness," paper presented at Open-mindedness and the Virtues in Education: A Conference Celebrating the work of Professor William Hare, Halifax, NS, October $3^{\text {rd }}$, 2008.]

${ }^{27}$ See, for example, the paper by Harvey Siegel in this special issue. Cohen's and Siegel's presentations at the conference, and a follow-up email exchange with Siegel, helped me think through these issues. I have not seen the final version of either paper, however.

${ }^{28}$ As I mentioned in note 5 , there are two variations here. It might be that running away is in fact the courageous choice in a given situation; it could also be that practical wisdom dictates that justice, kindness, or some other virtue is more salient than courage in the situation. Cohen, Miller and Siegel might then respond that tenacity (Cohen and Miller) or critical-thinking (Siegel) are parallel to justice and kindness here, so that it does make sense to speak of one being too open-minded in a particular situation, meaning that the agent has misread a situation as one calling for open-mindedness (or only open-mindedness). However, in what follows I will suggest that openmindedness fits the triadic model of virtue and is defined precisely against such vices as spinelessness and gullibility, making tenacity and criticality part of the mean that is OM. If Cohen, Miller, and Siegel accept my triadic model, then it might turn out that the only difference between our views is a semantic one over what to call the middle ground between rigidity and spinelessness, gullibility and suspiciousness. It might also be helpful here to distinguish between the (capital v) Virtue, which is the ideal mediation between vices and something known to us fallible humans only in theory, and the pair of (little v) virtues that represent the excellence in steering away from either extreme back toward the middle ground. Thus, lacking a compass to tell us true north, we find ourselves steering by tacking maneuvers, away from both gullibility and suspiciousness, or from both spinelessness and defensiveness. Perhaps, then, we could call tenacity the virtue by which we tack away from a perceived spinelessness, criticality the virtue by which we steer clear of gullibility, and open-mindedness the virtue by which we tack away from suspiciousness and defensiveness. On this model, we might call the Virtue defined by these related vice pairs simply Intelligence. 
goods to the degree in which we approximate what Dewey called continuity in experience. Experience is rich to the degree it forms a complex unity over time, and is impoverished when either its complexity or its coherence suffers. In one direction, experience deadens into monotony; in the other it fragments into chaos. To err on the side of giving new ideas too little purchase threatens that the circle of experience will narrow and run in a groove. ${ }^{29}$ To close myself off prematurely to what promises to correct and enrich my views is to sacrifice the good of contact with reality. To open myself too quickly or carelessly to revision is to sacrifice the coherence of my unfolding life narrative. Further, if the circle of experience spins into a fragmented jumping about from one view to the next, contact with reality also suffers, for part of what makes the world speak is the posing of rich questions to it, which requires commitment to a line of thought and relies on experience being funded with cumulative meanings.

I have tried to move from a binary model of open and closed-mindedness to one inspired by Aristotle's doctrine of the mean. What becomes clear, however, is that there are not simply two vices in question here, but a whole family of related vice pairs that together frame what is a multi-faceted intellectual virtue. The following diagram depicts the range of contrasts definitive of OM:

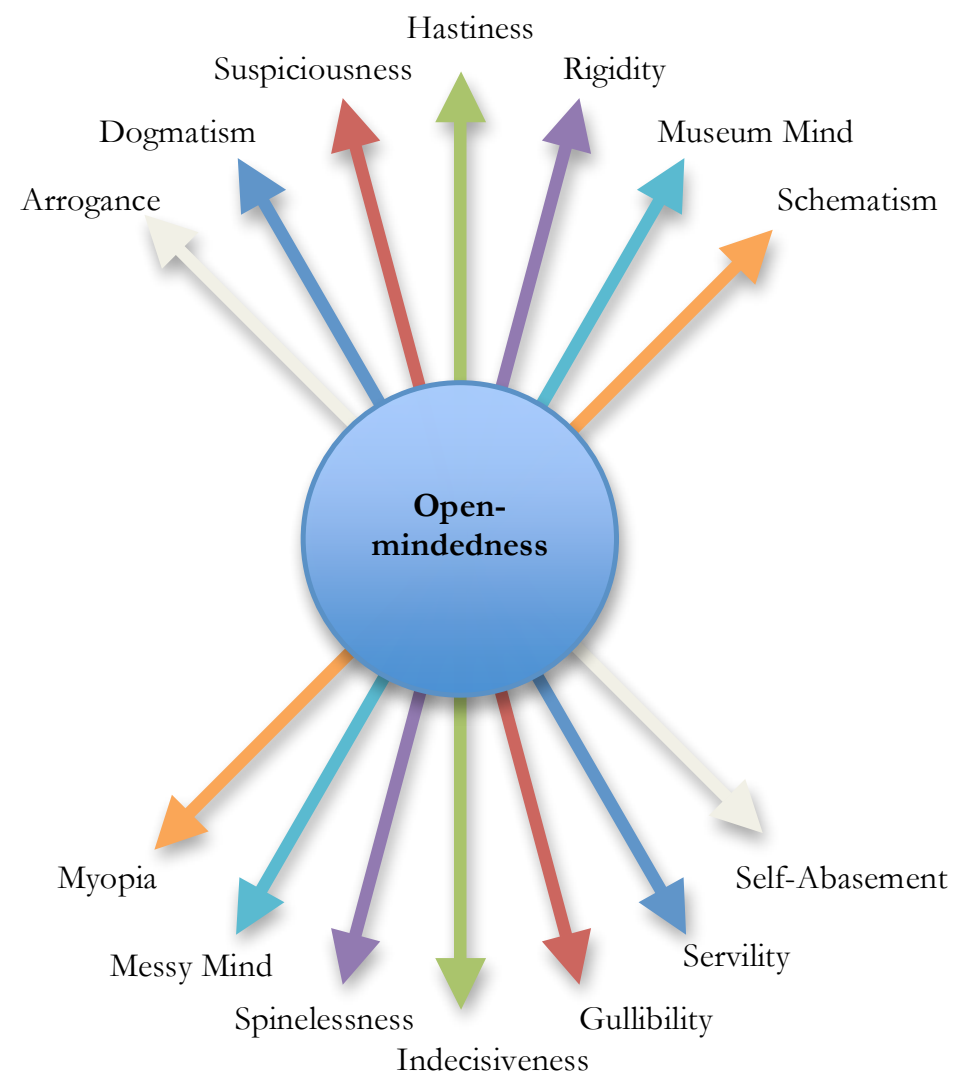

Diagram 1: Diagram 1: Open-mindedness as Defined by Seven Related Vice-Pairs

The complex intellectual virtue of open-mindedness requires that we find true humility, avoiding the drift both towards arrogance and intellectual self-abasement. It also requires that we find our balance in relation to new ideas, neither pressing forward dogmatically nor getting pushed around in

${ }^{29} \mathrm{On}$ the way the virtues themselves can be a source of repetition, see Lear, Happiness, Death, and the Remainder of Life, 62-67. 
servile fashion. Furthermore, the open-minded person knows how to combine what Peter Elbow calls the doubting and the believing games since both premature suspicion and gullible acceptance can trivialize new ideas. ${ }^{30}$ This connects with a more general concern to be neither too hasty nor too indecisive in thinking things through. Slightly different again is the idea of finding one's way between defensiveness and spinelessness. The hasty and defensive person slams the door on most new ideas. The indecisive and spineless person is not such much closed-minded as "empty-minded" in Dewey's phrase. As Dewey famously put it, while OM requires a kind of "hospitality to new themes, facts, ideas, questions, it is not the kind of hospitality that would be indicated by hanging out a sign: 'come right in, there's nobody at home." 31 Thus, OM would also seem to require the right sort of relation among one's ideas. As with the other axes, the mean here cannot be stated except negatively. One who keeps only a few carefully curated ideas (what I call museum mind), insisting that all ideas acquired have clear and perfectly consistent relations to one another, will be generally unreceptive to new ideas. At the same time, the person who admits ideas by the truckload, without any concern for how they fit together (messy mind), shows a kind of inclusion that fails to make a home for the new idea. Related to this is the pair of intellectual vices I have called schematism and myopia. To the schematic knower, who may well suffer from the museum mind just described, the acceptance or rejection of new ideas is somewhat beyond the point as ideas are abstracted to a point where their substance goes missing. The myopic knower suffers from the opposite problem, always zooming in too close to sense the connection of one idea with another, and thus in his own way failing to be open to the real meaning of ideas.

When we ask what open-mindedness is, the answer seems plain: it is an intellectual virtue. When we ask what $\mathrm{OM}$ is not, we arrive at the same place but with a richer sense of what is involved. When we recognize that every virtue has two opposites, and that in this case it is a whole cluster of vice pairs which define the excellence in question, what is revealed is an intellectual virtue with rich internal variegation.

\section{Where Is Open-mindedness?}

If $\mathrm{OM}$ is, as I have joined Hare in arguing, an intellectual virtue, then the answer to our third question would seem to be simple. OM is found in persons. Even in Aristotle, though, the answer is more complicated than this, since the acquisition and exercise of the virtues requires an ethos. The virtuous person needs exemplars and a communal sense of the good in which the virtues find their meaning. And it seems uncontroversial that, in the case of OM, there can be social, cultural, and political constraints on individual knowers. There is a parallel to moral luck here. Someone who is forbidden to go to the library may find it quite hard to cultivate $\mathrm{OM}$, at least in regard to certain ideas. However, the question I am raising here goes beyond such considerations. To see what I have in mind, we need to return to Plato and the Republic.

The Republic hinges on the analogy drawn by Socrates in Book II between city and soul, polis and psyche. The question under discussion is whether being just benefits the one who is just, whether the soul of the just person is in better shape than that of the unjust person. This has led the group to inquire into the nature and origins of justice and injustice. It is here that Socrates proposes his heuristic device:

${ }^{30}$ See, e.g., Peter Elbow, "Methodological Doubting and Believing: Contraries in Inquiry," in Embracing Contraries: Explorations in Learning and Teaching (New York: Oxford University Press, 1986), 254-300. Cf. the distinction between a hermeneutic of suspicion and of recovery in Paul Ricoeur, Frend and Philosophy: An Essay on Interpretation, trans. Denis Savage (New Haven: Yale University Press, 1970), 28-36.

31John Dewey, How We Think: A Restatement of the Relation of Reflective Thinking to the Educative Process (1910) (Boston: Houghton Mifflin, 1998), 30. 
SOCRATES: The investigation we are undertaking is not an easy one, in my view, but requires keen eyesight. So, since we are not clever people, I think we should adopt the method of investigation that we should use if, lacking keen eyesight, we were told to identify small letters from a distance, and then noticed that the same letters existed elsewhere in a larger size and on a larger surface. We would consider it a godsend, I think, to be allowed to identify the larger ones first, and then to examine the smaller ones to see whether they are really the same.

ADEIMANTUS: Of course we would. But how is this case similar to our investigation of justice in your view?

SOCRATES: I will tell you. We say, don't we, that there is a justice that belongs to a single man, and also one that belongs to a whole city?

AdeImantus: Certainly.

SOCRATES: And a city is larger than a single man?

ADEIMANTUS: Yes, it is larger.

SOCRATES: Perhaps, then, there will be more justice in the larger thing, and it will be easier to discern. So, if you are willing, let's first find out what sort of thing justice is in cities, and afterward look for it in the individual to see if the larger entity is similar in form to the smaller one. $^{32}$

The irony here is that what is supposed to be the easier course turns out to involve constructing a city from scratch, a city in speech. For in order to see justice at the political level, a just political order must be envisioned. And this is quite a project, occupying the interlocutors from this moment in Book II all the way to very end of Book X where the ethical argument is quickly deemed settled on the basis of the political argument. It is this fact, aided by Cicero's fateful translation of Politeia as Res Publica, that has led us to think of this as work of utopian political philosophy which just happens to get going through this strange analogical device.

As Jonathan Lear has argued, however, this is really to miss the point of both the word politeia and Plato's text by that name. One of the possible translations of politeia, Lear explains, is "constitutionality," and constitution is a word that applies equally well to persons and societies. ${ }^{33}$ Plato's dialogue, Lear suggests, is a book about what it means to be well constituted, about what it means to flourish as a differentiated unity or a complex whole. Thus Politeia is at once an ethical, political, and psychological study. It is a book about how psyches and poleis hang together and fall apart.

Still the question remains whether Plato is right that the struggles to constitute a whole polis out of the myriad, conflicting elements that populate a city is truly analogous to the struggle to constitute a personal unity out of the myriad, conflicting parts of the psyche. Lear's contention is that this is no mere analogical device-imagine if your soul was a city with warring constituents—but a genuine isomorphism in human life. ${ }^{34}$ For Lear, Plato is our first object-relations theorist. ${ }^{35}$ That is, he saw mind

${ }^{32}$ Plato, Republic (c. 380 B.C.E.), 3rd Rev. Ed., trans. C.D.C. Reeve (Indianapolis: Hackett, 2004), 46 [368c-369a].

${ }^{33}$ Seminar presentation, Fudan-UIUC Advanced Training and Research Seminar on Philosophy of Education, College of Education, University of Illinois, Champaign, IL, July 7-9, 2008.

34Jonathan Lear, "Inside and Outside the Republic," in Open Minded: Working out the Logic of the Soul (Cambridge, MA: Harvard University Press, 1998), 219-246. This chapter originally appeared as Jonathan Lear, "Inside and Outside the Republic," Phronesis: A journal for Ancient Philosophy 37, no. 2 (1992), 184-215. The Phronesis version includes the Greek phrases Lear translates. As Lear points out (p. 239, n. 51 in Open-Minded; p. 208, n. 116 in the Phronesis article), Plato actually never uses the word analogy here.

${ }^{35}$ Object relations is a branch of psychoanalytic theory, in which certain themes in Freud were developed by Melanie Klein, W.R.D. Fairbairn, D.W. Winnicott and others. 
as something which: (1) synchronically, exists at two scales: the individual and the group; (2) diachronically, is characterized by movement across these two scales.

The first of Plato's two considerations of mind spells out the challenge to the conventional wisdom that minds are solely or even primarily an individual possession. On this view, there may be meetings of minds in social space, and there may be social forces that impinge on minds, but mind itself is by definition something individual. Against this Lear maintains, with Plato, that social forms also represent mind at work. To explain why this is so, we need the diachronic principle: there is a flow over time of mental structures between these levels. Individual psychic structure is formed by internalization of social forms and relations; social structures are formed by externalization of human psychic life. This model is balanced between the two scales, but is also dynamic, showing how individual and cultural minding moves, evolves, degrades. Thus, when Socrates works through the case studies of the oligarchic person, the democratic person, and so on, he is showing us, in a somewhat schematic form, how a form of social life is likely to generate certain personalities and how these personalities in turn will yield certain new "socialities."

The point for our purposes is that if one is interested in the intellectual virtues and vices, then one must not only look at individual intellects but at social forms of minding and at the interplay between them. In the space remaining, I will develop one line of inquiry suggestive of the added dimensionality the "where" question allows. First, let us return for a moment to the concept of disavowal. Earlier we noted that closed-mindedness could take the form not of a simple rejection of the idea but of a kind of division within the self. The idea is allowed in but stripped of its force, confined to isolation. Now, given Plato's and Lear's urging to look for mind at work across scales, what might be the extrapersonal equivalent of this intrapersonal division?

In a word, I believe the answer lies in the phenomenon of subgrouping. To explain what I mean will require a quick rehearsal of psychodynamic Group-as-a-Whole theory (GWT). ${ }^{36}$ GWT comes in several variations, all of them intricate. What follows is a highly schematic account of some of the basic ideas. The first premise of GWT is the fact of human dependence, or rather our relation to that fact. Our first experiences of independence are terrifying. For as long as our basic needs are provided we feel completely held and indeed to some extent merged with our primary caretakers. Our wishes and their responses, when things are clicking, seem to us magically attuned. When, however, their response is too quick or too slow, or somehow off the mark, not to mention when they are absent, we begin to learn what it means to be a self. You could say we learn the meaning of self-insufficiency.

From our adult perspective, these inevitable gaps in the provision of fundamental, early care should not be considered failures. Perfect care is not only impossible but undesirable since it would stifle development: as Winnicott said, by definition the best a parent can be is "good enough." 37 But of course the infant does feel let down and bitterly so. And this puts the infant in a cognitive predicament. Such failures, as the child views them, point to the fact that the mother, let us say, is sometimes bad, a potential source of pain and disappointment. From a mature perspective (whenever we are lucky enough to find one), the conclusion is just this, that the mother is an ambiguous object, not wholly good, and certainly not wholly bad. But it is precisely this both/and logic that is difficult for human beings in touch with their extreme dependency. It causes tremendous anxiety to acknowledge that the being on whom one utterly depends is even partly bad. Since the human mind does not enjoy anxiety one bit, it has developed some rather clever if short-sighted ways of dealing with it. For the purposes of this rapid-fire tour of GWT, one stands out: splitting. Splitting is a mechanism for coping with anxiety in which, in our imagination, we separate the conflicting qualities we find in someone on whom we

${ }^{36}$ With this term, I am referring to the blend of psychoanalytic and systems-theoretic approaches to group life building on the work of Melanie Klein, Wilfred Bion, and Kurt Lewin, associated with the Tavistock institute in the UK and with the National Training Laboratory and AK Rice institute in the U.S.

${ }^{37}$ See, e.g., Donald W. Winnicott, Playing and Reality (1971) (London: Routledge, 1991), 139. 
depend. ${ }^{38}$ There are endless variations on this maneuver. The child may imaginatively relocate the bad aspects of the mother into another person or into a specific part of the mother. Or, in a desperate maneuver, the child may introject the bad into himself in order to keep the parent pristine.

This is the background for GWT. The theory proper begins when adults later come together in groups. What do we mean by an adult? What we do not mean is someone who has navigated these treacherous early struggles with dependence and independence completely successfully, with no residue. Such people may exist but we are talking about ordinary human beings who all bear some marks of the ordeal of dependence. GWT predicts that entry into groups, joining something larger than myself, is perfectly suited to stirring up these old issues. Participation in group life, where most of life is lived, promises and threatens merger. It reactivates our ambivalences around dependence.

The breakthrough in GWT came in Wilfred Bion's work with small therapeutic groups dealing with the traumas of World War II. ${ }^{39}$ He began with a fairly conventional view on the matter: individuals come together to form a group, more or less well, to meet their individual needs. At some point in his work, however, he achieved a fundamental shift in perspective: groups have their own identity and agency, and it is just as fair to say that they assign individual personas to meet their collective needs. This may sound like a classic division of labor, but the difference is that the division tends to go on surreptitiously and the labor often seems to undermine the official task. What Bion discovered was that the group was behaving much like a psychoanalytic patient who would enact its dilemmas unconsciously, needing the psychoanalyst to help the patient see, avow, and name these unconscious enactments.

The idea is that for a group to form, it requires individuals to identify with one another, the collective, and the task. These identifications make possible the very processes of projection and introjection that characterize early life. Add to this that joining something larger than oneself stirs up one's basic ambivalences about dependence, independence, and relation, and we have a volatile recipe. Groups evoke, collect, and then redistribute conflictual feelings around:

- Belonging: wishes for inclusion and autonomy; fears of ostracism and engulfment.

- Dependence: wishes to be taken care of; fears of being let down.

- Intimacy: wishes to be close and to receive affection; fears of being vulnerable and of being unworthy of affection.

- Authority: wishes to be relieved of the burden of directing one's actions; resentments at being told what to do.

When I speak of redistribution, I am referring to what is by now well-documented as a persistent, central feature of group life: subgrouping. ${ }^{40}$ Imagine a group of people coming together, each of whom struggles with each of these ambivalences. Suddenly they are thrust into a setting in which these feelings become both heightened (since the joining of group reactivates them in a strong way) and more labile (since the mechanisms of identification make possible very fluid projections in which I allow others to stand in imaginatively for parts of myself I disavow or endorse). The group thus rapidly becomes a repository of the feelings on both sides of each of these equations, and it must find a way to contain these feelings. The group itself resorts to splitting! Subgroups are formed: some members seem to carry the banner for the group: "Join, join, join," they say. Others sit on the edge of

${ }^{38}$ For a key early essay on splitting, see Melanie Klein, "Notes on Some Schizoid Mechanisms," in The Writings of Melanie Klein, Volume 3: Enyy and Gratitude and Other Works, 1946-1963 (New York: Free Press, 1975).

${ }^{39}$ See, e.g., Wilfred R. Bion, Experiences in Groups: And Other Papers (1961) (New York: Routledge, 2004).

${ }^{40}$ On subgrouping, see, e.g., Warren G. Bennis and Herbert A. Shepard, "A Theory of Group Development," Human Relations 9, no. 4 (1956); and, Leroy Wells, "The Group as a Whole: A Systemic Socioanalytic Perspective on Interpersonal and Group Relations," in Groups in Context: A New Perspective on Group Dynamics, eds. Jonathon Gilette and Marion McCollum (Reading, Mass.: Addison-Wesley, 1990). 
their seat, expressing with every fiber that they are there under duress and soon to leave. One faction brings up that the group should have more activities in which the members get to know each other. Another faction resists and mocks these rituals. What Bion claims to have seen, and what is indeed very striking when one does experiential, group-dynamics work, is the unity of these seeming crosspurposes. One can experience a kind of gestalt shift in which the various factions and splinter groups suddenly appear to have cannily divided up the labor of a common task: simultaneously to strive for and resist intimacy and belonging, authority and dependence. The group has found a way, though a tense and uneasy one, to be a differentiated unity, a complex whole: to be constituted.

From GWT with its emphasis on small group dynamics, we can extrapolate to splitting at larger levels. We see entrenched camps, polemical debates in which neither side seems to be able to listen to the other, and we think (usually of people in the other camp): why can't people be more open-minded? What this excursus through Plato and GWT has shown, however, is that these polemical divisions are themselves an instance of mind at work, of mind holding apart ideas that it cannot bear or does not know how to think together, of mind holding itself together by desperate measures. By posing the question of where open-mindedness is located, we have caught yet another sense of what open- and closed-mindedness may mean. The alien idea with which we refuse to engage may be less foreign than it appears, for it may well be an idea of our own which we cannot tolerate, which in imagination we have located elsewhere. Meanwhile, what may look like trying to get through to the other camp may turn out to be making sure that our baggage remains safely stowed. Thus, we return at the group level to an idea broached in the first section, namely that open-mindedness is closely related to integrity. To be openminded as a person or as a group means to work from ambivalence and disavowal towards ambiguity and re-integration.

\section{Conclusion}

The aim of this essay has been programmatic. I have tried to show something of the range of this key intellectual virtue, by examining it along three distinct dimensions. I have sought to unfold OM temporally, dialectically, and spatially. In the process, we have discovered that in addition to the more familiar associations such as humility and the concern for truth, $\mathrm{OM}$ also concerns aesthetic perception, existential continuity, and the dynamics of intra- and interpersonal re-integration. There is a tension built into the idea of the virtues, between stability and change, repetition and innovation. Virtues are stable dispositions which offer substance to a person and coherence to a life. And yet, practical wisdom is a prerequisite for possession of the virtues, and practical wisdom involves precisely an openness to concretizing, extending, and revising one's moral knowledge in light of new, irreducible situations in which one finds oneself. Like Aristotle's phronesis, Jane Austen's "constancy," or Dewey's continuity, open-mindedness speaks to this essential tension and balance in human life and may well, like these other concepts, represent a sort of meta or organizing virtue. ${ }^{41}$

Jonathan Lear has suggested that to be open-minded is to possess "the capacity to live nondefensively with the question of how to live." 42 As Lear goes on to remark, we might well read "human life in general [as] a study of why this capacity is not exercised: why open-mindedness is, for the most part, evaded, diminished, and attacked." 43 To this we might add that open-mindedness is often treated with that special form of contempt that takes the form of bland acceptance. I have tried in this essay to

\footnotetext{
${ }^{41}$ On the role of constancy in Austen's (informal) account of the virtues, see MacIntyre, After Virtue, 182-183.

${ }^{42} J$ onathan Lear, Open Minded: Working out the Logic of the Soul (Cambridge, MA: Harvard University Press, 1998), 8; cf. 4 ff.

${ }^{43}$ Ibid., 8.
} 
survey the range of individual and social forces which threaten open-mindedness so that we might gain a fresh appreciation of the vital importance and complex structure of this central intellectual virtue.

\section{Acknowledgments}

I presented an earlier version of this essay at Open-mindedness and the Virtues in Education: A Conference Celebrating the work of Professor William Hare (Halifax, NS; October 2nd-4th, 2008). I would like to thank the conference organizers for providing this stimulating and congenial occasion, and the audience for their enthusiastic reception and questions. I am grateful to Michelle Forrest, Bill Hare, and Eva Knoll for their interest in my work, and special thanks to Michelle for her editorial patience and support. I would also like to take this opportunity to express my gratitude to Jonathan Lear: when I was an undergraduate at Yale, Jonathan showed me what it means to practice philosophy as a humane discipline; I have continued to learn a great deal from his writings over the years, especially about how to marry my interests in philosophy and psychoanalysis; and, I recently had the chance to sit in on a seminar he taught on the Republic, an experience which directly inspired parts of this paper and reminded me what it means to read a book in a serious way. Finally, this essay, like all of my work, owes everything to Jennifer Burns for her tireless and loving, direct and indirect support of my writing.

\section{About the Author}

Chris Higgins is Assistant Professor in the Department of Educational Policy Studies at the University of Illinois at Urbana-Champaign. A philosopher of education, his scholarly interests include dialogue and the teacher-student relationship, imagination and aesthetic education, professional education and the nature of work, teacher motivation and professional ethics, humanism and liberal learning. His recent publications include "Human Conditions for Teaching: The Place of Pedagogy in Arendt's Vita Activa" (Teachers College Record), "Modest Beginnings of a Radical Revision of the Concept of Imagination" (in S. Blenkinsop, ed., The Imagination in Education: Extending the Boundaries of Theory and Practice, Cambridge Scholars Publishing), and "Humane Letters: Notes on the Concept of Integrity and the Meanings of Humanism" (Philosophical Studies in Education). His forthcoming book is entitled The Good Life of Teaching: Toward a Virtue Ethics for Teachers (Wiley-Blackwell). 